\title{
Evaluation by ELISA of Anisakis simplex Larval Antigen Purified by Affinity Chromatography
}

\author{
M Rodero, A Jiménez, C Cuéllar ${ }^{+}$
}

Departamento de Parasitología, Facultad de Farmacia, Universidad Complutense, 28040 Madrid, España

In order to improve the specificity and sensitivity of the techniques for the human anisakidosis diagnosis, a method of affinity chromatography for the purification of species-specific antigens from Anisakis simplex third-stage larvae (L3) has been developed. New Zealand rabbits were immunized with A. simplex or Ascaris suum antigens or inoculated with Toxocara canis embryonated eggs. The IgG specific antibodies were isolated by means of protein ASepharose CL-4B beads columns. IgG anti-A. simplex and -A. suum were coupled to CNBr-activated Sepharose $4 B$. For the purification of the larval A. simplex antigens, these were loaded into the anti-A. simplex column and bound antigens eluted. For the elimination of the epitopes responsible for the cross-reactions, the A. simplex specific proteins were loaded into the anti-A. suum column. To prove the specificity of the isolated proteins, immunochemical analyses by polyacrylamide gel electrophoresis were carried out. Further, we studied the different responses by ELISA to the different antigenic preparations of A. simplex used, observing their capability of discriminating among the different antisera raised in rabbits (anti-A. simplex, anti-A. suum, anti-T. canis). The discriminatory capability with the anti-T. canis antisera was good using the larval A. simplex crude extract $(C E)$ antigen. When larval A. simplex $C E$ antigen was loaded into a CNBr-activated Sepharose $4 B$ coupled to Ig G from rabbits immunized with $\mathrm{A}$. simplex $C E$ antigen, its capability for discriminate between $\mathrm{A}$. simplex and $\mathrm{A}$. suum was improved, increasing in the case of $\mathrm{T}$. canis. The best results were obtained using larval A. simplex $C E$ antigen loaded into a CNBr-activated Sepharose $4 B$ coupled to Ig $G$ from rabbits immunized with adult A. suum $C E$ antigen. When we compared the different serum dilution and antigenic concentration, we selected the working serum dilution of $1 / 400$ and $1 \mu \mathrm{g} / \mathrm{ml}$ of antigenic concentration.

Key words: Anisakis simplex - antigen purification - affinity chromatography - ELISA - rabbit antisera

The diagnosis of human anisakidosis can be made from the history of eating raw fish, and a final diagnosis is not easy even with the development of gastrofiberscopical examination of patients (Ishikura et al. 1993), and in most cases it is only correctly made after post-operative pathological examination of the affected part of the gut. In intestinal anisakiasis post-operative diagnosis is made by identification of whole larvae or cross sections of larvae in histological sections (Smith \& Wootten 1978). Consequently, anisakidosis has often been misdiagnosed as appendicits, acute abdomen, gastric tumour or cancer, ileitis, cholecystitis, diverticulitis, tuberculous peritonitis, cancer of the pancreas, or Crohn's disease (Sakanari \& McKerrow 1989). Immunodiagnostic methods have been developed, but several cross-reactivities have appeared. The earliest method for immunodiagnosis of anisakiasis was a complement fixation text (Daniels 1962). A immunofluorescence test was more sensitive than complement

This research was supported by SAF98-0072 (Comisión Interministerial de Ciencia y Tecnología). Marta Rodero is supported by a fellowship from International Pharmaceutical Immunology, Atache, Smaller, Alacan, Centrum, Agrupación de Interés Económico.

${ }^{+}$Corresponding author. Fax: +34-91-394.1815. E-mail: cuellarh@farm.ucm.es

Received 23 March 2001

Accepted 8 November 2001 fixation, but cross-reactions with sera from toxocariasis patients can occur (Ruitemberg 1970). Immunoelectrophoresis on starch demonstrated cross-reactivity to antigens from both Toxocara and Ascaris (Suzuki 1968). Iglesias et al. (1996) observed that the murine sera raised by immunization with Ascaris suum, Toxocara canis and Hys-terothylacium aduncum somatic antigens reacted even more strongly with the Anisakis simplex antigen than with the corresponding homologous by ELISA and immunoblotting. In fact, extensive homology between both somatic and excretory-secretory antigens of $A$. simplex and other ascaridoid nematodes mainly A. suum, A. lumbricoides and T. canis has been reported (Kennedy et al. 1988).

In this work the specificity and sensitivity of $A$. simplex antigens prepared by affinity chromatography were assayed by ELISA using sera from immunized animals.

\section{MATERIALS AND METHODS}

Parasites - A. simplex L3 were picked up manually from the viscera, flesh and body cavities of naturally infected blue whiting (Micromesistius poutassou) and exhaustively washed in water (Perteguer \& Cuéllar 1998). A. suum and $T$. canis were obtained from natural infections of swine or dogs, respectively. T. canis eggs were obtained by dissection of gravid females and, after their purification, they were embryonated under sterile conditions and preserved at $4^{\circ} \mathrm{C}$ until use (Guillén et al. 1986).

Antigens - For preparation of the crude extract (CE) of A. simplex (A. simplex $\mathrm{CE}$ antigen), $\mathrm{L} 3$ were placed at $4^{\circ} \mathrm{C}$ in PBS. This material was homogenized in a hand-oper- 
ated glass tissue grinder at $4{ }^{\circ} \mathrm{C}$, followed by sonication for $10 \mathrm{~s}$ with a Virsonic 5 (Virtis, NY, USA) set at 70\% output power. The homogenate was extracted in PBS at $4^{\circ} \mathrm{C}$ overnight and, subsequently, delipidized with n-hexane and then centrifuged at $8,497 \mathrm{~g}$ for $30 \mathrm{~min}$ at $4^{\circ} \mathrm{C}$ (Biofuge 17RS: Heraeus Sepatech, Gmb, Osterode, Denmark). The supernatant was dialysed overnight at $4{ }^{\circ} \mathrm{C}$ in PBS. Protein content of the extract was estimated and the extract was frozen at $-20^{\circ} \mathrm{C}$ until used (Perteguer \& Cuéllar 1998). CE antigen from A. suum adults (A. suum CE antigen) was obtained using a modification of the Welch et al. (1983) method by homogenization and extraction in PBS at $4^{\circ} \mathrm{C}$ overnight (instead of ultrasonic burst). Its protein content was estimated by the Bradford (1976) method, and then the antigen frozen at $-20^{\circ} \mathrm{C}$ until use (Águila et al. 1987, Cuéllar et al. 1990). T. canis eggs were obtained by dissection of gravid females, resulting from a natural infection. After purification, they were embryonated under sterile conditions at $37^{\circ} \mathrm{C}$ and preserved at $4^{\circ} \mathrm{C}$ until use (Guillén et al. 1986, Fenoy et al. 1987, 1988).

Hyperimmune sera - New Zealand rabbits of about 3 $\mathrm{kg}$ body weight were immunized with larval $A$. simplex or adult $A$. suum $\mathrm{CE}$ antigen as multiple doses of $3 \mathrm{ml}$ of antigen $(1,000 \mu \mathrm{g} / \mathrm{ml}$ in final volume) in Freund's Complete Adjuvant (FCA) intramuscularly given weekly for 3 weeks. Other New Zealand rabbits were inoculated with multiple doses of 2,000 embryonated eggs of $T$. canis weekly, during 4 weeks, by oral administration with gastric tubing. Animals were bled weekly postimmunization (p.i.) after the 1st inoculation (week 0) (Cuéllar et al. 1990, García et al. 1996).

Purification of A. simplex CE products by affinity chromatography - Protein A-Sepharose CL-4B beads (Pharmacia Biotech) columns were prepared according to the manufacturer's instructions. Rabbit anti-A. simplex, or $-A$. suum antibodies, in sample buffer [0.05 M Tris, 0.5 $\mathrm{M} \mathrm{NaCl}(\mathrm{pH}$ 8.0)] were loaded into the columns. Fractions of $1 \mathrm{ml}$ were then collected. Unbound immunoglobulins were washed with washing buffer $(0.05 \mathrm{M}$ Tris, $0.5 \mathrm{M}$ $\mathrm{NaCl})$. Bound immunoglobulins then were eluted with glycine buffer $(0.2 \mathrm{M}$ glycine, $0.5 \mathrm{M} \mathrm{NaCl}, \mathrm{pH} 2.8)$. Fractions were collected onto $100 \mu$ l of collection buffer (Tris-base $1 \mathrm{M}, \mathrm{pH} 8.5$ ) and read on a spectrophotometer at $\mathrm{A}_{280}$ for calculating IgG concentration. A column was prepared with Protein A affinity isolated IgG anti-A. simplex, at a concentration of $5 \mathrm{mg} / \mathrm{ml}$ in $\mathrm{NaHCO}_{3} 0.1 \mathrm{M}$ with $\mathrm{NaCl} 0.5$ $\mathrm{M}$ (pH 8.5) coupled to CNBr-activated Sepharose 4B according to the manufacturer's instructions (Pharmacia Biotech). A. simplex $\mathrm{CE}$ antigen in sample buffer was loaded into the column and incubated $3 \mathrm{~h}$ at room temperature. Fractions of $1 \mathrm{ml}$ were then collected. Unbound antigens were washed with washing buffer and bound antigens were then eluted with glycine buffer followed by $50 \mathrm{mM}$ diethylamine in saline, $\mathrm{pH} 11.5$ and collected into glycine to neutralise the eluted fractions. Fractions were read at $\mathrm{A}_{280}$. This antigen was named as A. simplex PAK antigen. The same procedure was carried out using columns prepared with rabbit IgG anti-A. suum, obtaining the A. simplex PAS antigen and the A. simplex EAS antigen.

$S D S-P A G E$ - Sodium dodecylsulphate-polyacrilamide gel electrophoresis (SDS-PAGE) was carried out as de- scribed by Laemmli (1970) and revised by Hames (1986) using a Mini Protean ${ }^{\circledR}$ II cell (Bio Rad). The gels consisted of a $4 \%$ stacking gel and a 5-20\% gradient separating gel. Samples were dissolved in a sample buffer (50 $\mathrm{mM}$ Tris-HCl buffer, $\mathrm{pH} 8.6$, containing $2 \%$ SDS, $20 \%$ glycerol and $0.02 \%$ bromophenol blue) diluted $1: 1$ in electrode buffer (25 mM Tris, $192 \mathrm{mM}$ glycine, $\mathrm{pH}$ 8.3), containing $1 \%$ SDS. Electrophoresis was performed for $2 \mathrm{~h}$ at a constant $100 \mathrm{~V}$ in Tris-glycine electrode buffer (see above). Broad range molecular weight markers (6500-205,000 or 7200-209,000 Da, Bio Rad) were incorporated into each electrophoretic run. Gels were stained with silver.

Determination of specific antibody levels - The 96 well microtitre plates (Nunc-Immuno Plate PolySorp ${ }^{\mathrm{TM}}$ ) were sensitized overnight at $4^{\circ} \mathrm{C}$ by the addition of $100 \mu \mathrm{l} /$ well of antigen diluted at $0.5 \mathrm{or} 1 \mu \mathrm{g} / \mathrm{ml}$ in a $0.1 \mathrm{M}$ carbonate buffer, $\mathrm{pH} 9.6$. After washing three times with $0.05 \%$ PBS-Tween 20 (PBS-Tween), wells were blocked by the addition of $200 \mu \mathrm{l}$ per well of $0.1 \% \mathrm{BSA}$ in PBS, for $1 \mathrm{~h}$ at $37^{\circ} \mathrm{C}$. After washing, $100 \mathrm{ml}$ of duplicate dilutions of rabbit sera at $1 / 100,1 / 200$ or $1 / 400$ in PBS-Tween, containing $0.1 \%$ BSA were added and incubated at $37^{\circ} \mathrm{C}$ for $2 \mathrm{~h}$. Once the plates were washed, $100 \mu \mathrm{l}$ per well of affinity isolated, peroxidase conjugated, goat anti-rabbit IgG (Caltag Laboratories, San Francisco, CA, USA), at the appropriate dilution in PBS-Tween, 0.1\% BSA, were incubated for $1 \mathrm{~h}$ at $37^{\circ} \mathrm{C}$. After adding substrated (phosphatecitrate buffer, containing $0.04 \% \mathrm{H}_{2} \mathrm{O}_{2}$ and $0.04 \%$ o-phenylenediamine) the reaction was stopped with $3 \mathrm{~N}$ sulfuric acid and the plates were read at $490 \mathrm{~nm}$ (García et al. 1996). Results were expressed as O.D.p-O.D.c indexes by subtracting the mean optical density (O.D.) of the control from the mean O.D. of the test sera once the non-specific reaction with the BSA used in the blocking was subtracted.

\section{RESULTS}

The electrophoresis comparative study between the A. simplex $\mathrm{CE}$ antigen and the one represented by the mixed fractions eluted with glycine buffer followed by diethylamine from the Sepharose 4B-rabbit IgG anti-A. simplex column (A. simplex PAK antigen) indicates that both preparations are very similar (Fig. 1).

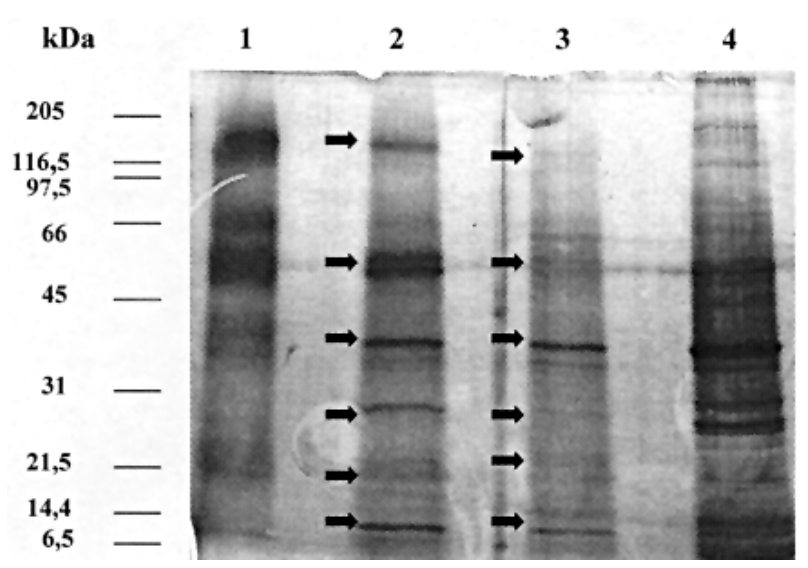

Fig. 1: SDS-PAGE, lane 1: Anisakis simplex EAS antigen; lane 2: A. simplex PAS antigen; lane 3: A. simplex PAK antigen; lane 4: A. simplex $\mathrm{CE}$ antigen. See arrows for $A$. simplex specific proteins 
Likewise, A. simplex PAK antigen was loaded into the column prepared with anti-A. suum rabbit IgG. Unbound (A. simplex free $A$. suum antigens) antigens were washed and bound (cross-reacting $A$. suum antigens) antigens eluted. After passing across the anti-Ascaris column, the proteins of A. simplex PAK antigen were maintained but increased in intensity the bands of 40 and $14 \mathrm{kDa}$. With $A$. simplex PAK antigen a doublet around $60 \mathrm{kDa}$ appeared. With the A. simplex PAS antigen, $60 \mathrm{kDa}$ was maintained with a high intensity. Bright bands of high molecular weight of about 209 and $150 \mathrm{kDa}$ were seen. In Fig. 1 electrophoretic patterns obtained with the above mentioned antigens by SDS-PAGE are shown. In the A. simplex PAK the previously mentioned doublet is shown. In the A. simplex PAS antigen the protein of $120 \mathrm{kDa}$ increased in concentration, as well as, a doublet of about $66-45 \mathrm{kDa}$, the protein of $40 \mathrm{kDa}$ was maintained but increased in intensity the protein of $25 \mathrm{kDa}$, and a doublet between 21.5 and $14 \mathrm{kDa}$. In the $A$. simplex EAS antigen debris of rabbits IgG were observed at 97-66 kDa. Likewise, very bright proteins of about $35 \mathrm{kDa}$ and $7 \mathrm{kDa}$ were present.

Further, the ELISA method has been carried out in order to determine the IgG levels in sera from rabbits experimentally immunized with larval $A$. simplex or adult $A$. suum $\mathrm{CE}$ antigen as multiple doses in FCA intramuscularly or multiple doses of $T$. canis embryonated eggs. After they were bled weekly p.i., the sera with strong reactions were selected by ELISA against their homologous antigens. The selected rabbit antisera were tested at the $1 / 100$, $1 / 200$

or $1 / 400$ dilutions and the antigens at 1 or $0.5 \mu \mathrm{g} / \mathrm{ml}$. The antigenic preparations used were as follows: larval A. simplex $\mathrm{CE}$ antigen (A. simplex $\mathrm{CE}$ antigen); A. simplex $\mathrm{CE}$ antigen after loading into a $\mathrm{CNBr}$-activated Sepharose 4B coupled to IgG from rabbits immunized with $A$. simplex $\mathrm{CE}$ antigen (A. simplex PAK antigen); A. simplex PAK antigen after loading into a CNBr-activated Sepahrose 4B coupled to IgG from rabbits immunized with adult $A$. suum CE antigen (A. simplex PAS antigen); A. simplex PAK antigen eluted from the anti-A. suum column (A. simplex EAS antigen) and adult $A$. suum $\mathrm{CE}$ antigen (A. suum $\mathrm{CE}$ antigen). Results were expressed as O.D.p-O.D.c indexes by substracting the mean optical density of the test sera once the non-specific reaction with the BSA used in the blocking was substracted (Figs 2,3).

When the capability of the different antigens to discriminate among the different antisera raised in rabbits was studied, the minimal responses were observed using sera from rabbits inoculated per os with $T$. canis embryonated eggs against all the antigenic preparations used. The highest responses were obtained when the sera from rabbits immunized with larval A. simplex or adult $A$. suum CE were tested against their corresponding homologous and heterologous CE from A. simplex or A. suum. In order to study the different antigenic preparations of $A$. simplex used we have obtained an index as the ratio between the optical density resulting from the anti-A. simplex antiserum and the optical density of the anti-A. suum or anti-T. canis heterologous antisera once their corresponding nonspecific reaction with the BSA used in the postcoating were substracted, as well as, the optical density of the negative controls. In the case of the A. simplex CE antigen those indexes were between 0.7 (serum dilution 1/ 100 -antigen concentration $0.5 \mu \mathrm{g} / \mathrm{ml}$ ) and 1.7 (serum dilution $1 / 200$ and $1 / 400$-antigen concentration $0.5 \mu \mathrm{g} / \mathrm{ml}$ ) using anti-A. suum antisera. On the contrary, the discriminatory capability with anti-T. canis antisera was good with indexes situated between 5.1 (serum dilution 1/100-antigen

concentration $1 \mu \mathrm{g} / \mathrm{ml}$ ) and 14 (serum dilution 1/200-antigen concentration $0.5 \mu \mathrm{g} / \mathrm{ml}$ ). When A. simplex PAK antigen was tested, its capability for discriminate between A. simplex and $A$. suum was improved with indexes situated between 1.7
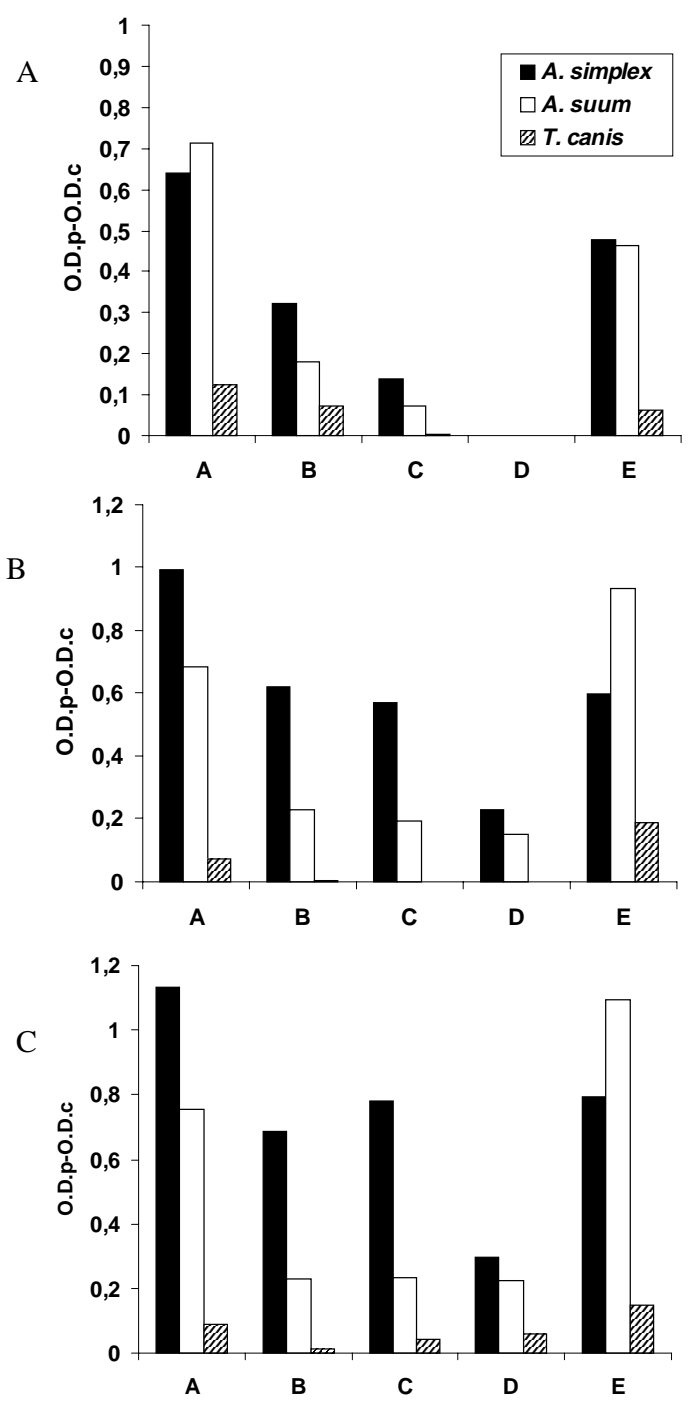

Fig. 2: ELISA IgG responses expressed as O.D.p-O.D.c indexes with serum samples. A: at 1/100; B: at $1 / 200$ and C: at $1 / 400$, of rabbits respectively immunized with Anisakis simplex crude extract (CE) antigen, Ascaris suum CE antigen, or Toxocara canis embryonated eggs, against the following antigens diluted at $1 \mu \mathrm{g} / \mathrm{ml}$ : larval $A$. simplex $\mathrm{CE}$ antigen (A. simplex $\mathrm{CE}$ antigen); A. simplex $\mathrm{CE}$ antigen treated in a IgG anti-A. simplex CE column (A. simplex PAK antigen); A. simplex PAK antigen treated in a IgG immunized anti- $A$. suum CE column (A. simplex PAS antigen); A. simplex PAK antigen eluted from the A. suum column (A. simplex EAS antigen); adult $A$. suum antigen (A. suum $\mathrm{CE}$ antigen) 
(serum dilution 1/100-antigen concentration $1 \mu \mathrm{g} / \mathrm{ml}$ ) and 3 (serum dilution 1/400-antigen concentration $1 \mu \mathrm{g} / \mathrm{ml}$ ), increasing in the case of $T$. canis from 4.3 (serum dilution $1 / 100$-antigen concentration $1 \mu \mathrm{g} / \mathrm{ml}$ ) to 103.3 (serum dilution $1 / 200$-antigen concentration $1 \mu \mathrm{g} / \mathrm{ml}$ ).

Using $A$. simplex PAS antigen, with anti-A. suum antisera, we obtained values from 1.8 (serum dilution 1/100antigen concentration $1 \mu \mathrm{g} / \mathrm{ml}$ ) to 3.3 (serum dilution $1 / 400$-antigen concentration $1 \mu \mathrm{g} / \mathrm{ml}$; serum dilution $1 / 100$ antigen concentration $0.5 \mu \mathrm{g} / \mathrm{ml}$ ). In the case of $T$. canis with the A. simplex PAS antigen the values were from 4.6 (serum dilution 1/100-antigen concentration $1 \mu \mathrm{g} / \mathrm{ml}$ ) to

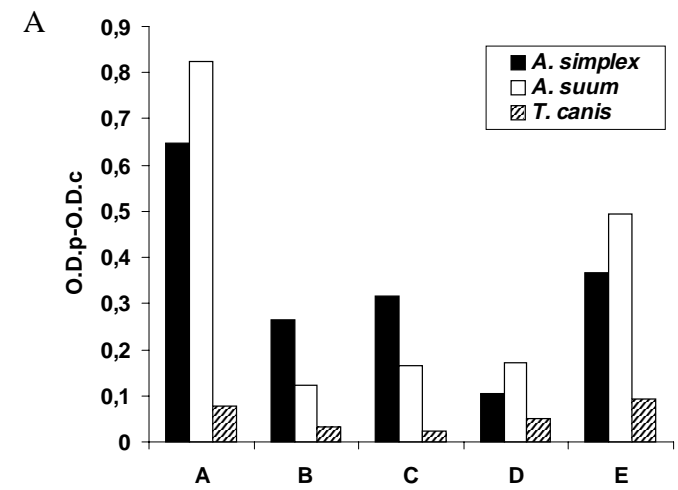

B
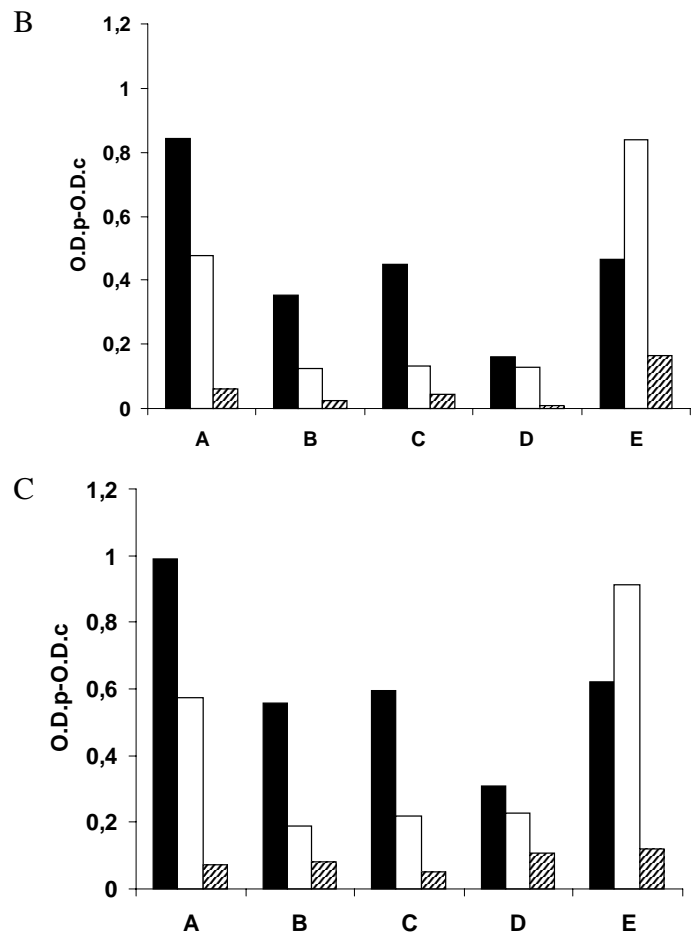

Fig. 3: ELISA IgG responses expressed as O.D.p-O.D.c indexes with serum samples. A: at $1 / 100$; B: at $1 / 200$ and C: at $1 / 400$, of rabbits respectively immunized with Anisakis simplex crude extract (CE) antigen, Ascaris suum CE antigen, or Toxocara canis embryonated eggs, against the following antigens diluted at $0.5 \mu \mathrm{g} / \mathrm{ml}$ : larval $A$. simplex $\mathrm{CE}$ antigen (A. simplex $\mathrm{CE}$ antigen); $A$. simplex $\mathrm{CE}$ antigen treated in a IgG anti-A. simplex CE column (A. simplex PAK antigen); A. simplex PAK antigen treated in a IgG immunized anti- $A$. suum CE column (A. simplex PAS antigen); A. simplex PAK antigen eluted from the A. suum column (A. simplex EAS antigen); adult $A$. suum antigen (A. suum $\mathrm{CE}$ antigen)
571 (serum dilution 1/200-antigen concentration $1 \mu \mathrm{g} / \mathrm{ml}$ ). In summary, to eliminate the cross-reactivity between $A$. simplex and $T$. canis and $A$. suum it is necessary a sequential step affinity chromatography using $\operatorname{IgG}$ from rabbits immunized with $A$. simplex and $A$. suum.

\section{DISCUSSION}

The aim of this work was to assay by ELISA the specificity and sensitivity of larval A. simplex $\mathrm{CE}$ antigen purified by means of affinity chromatography using sera from rabbits experimentally immunized.

The first purification step consisted in binding the larval $A$. simplex antigen to homologous antibodies from rabbits experimentally immunized with this antigen and eluted from the column in order to eliminate the major cross-reactivity molecules. The SDS-PAGE patterns of $A$. simplex CE antigen showed proteins of 205, 120, 66-45, 40, 31-21 and $14 \mathrm{kDa}$. In the A. simplex PAK antigen we observed the same proteins but several were in different proportions. The molecular mass of ABA-1, the Ascaris nematode polyprotein, is controversial, it has been previously estimated at 14,000 Da (Christie et al. 1990), but mass spectrometry analysis indicated that there were five componentes of similar size, with the major species being $14,643.2 \pm 1.4$ Da with a high degree of similarity amongst ascaridid parasites (Christie et al. 1993). Yahiro et al. (1998) cloned the cDNA of TBA-1, the nematode polyprotein allergen of $T$. canis, and on the basis of the amino acid sequence found it to be most similar to ABA-1. They observed a transient TBA-1 IgG antibody response during the infection that could explain the failure of Kennedy et al. (1989) in the aim of finding anti-TBA-1 antibodies in animals infected with $T$. canis for a prolonged period. Also different forms of ABA-1 have been reported by Kato and Komatsu (1996), which could explain the different antibody recognition such, also two different forms of TBA1 may be expressed in a stage specific manner. Also Kennedy et al. (1988) observed evidence that a Mr 14,000 component of $A$. simplex has a homologue in $A$. suum, $A$. lumbricoides and $T$. canis, but did not elicit an antibody response in anisakiasis.

Zarnowska and Jastrzebska (1994) by SDS-PAGE of larval ES products from $T$. canis showed polypeptides of molecular weights ranging from 19 to $200 \mathrm{kDa}$. However, an additional polypeptide, not observed on stained gels, and resolving at $14 \mathrm{kDa}$, was detected by immunoblotting. Sera from patients with $A$. lumbricoides recognized polypeptides of 74, 75 and $160 \mathrm{kDa}$. Iglesias et al. (1996) confirmed by immunoblotting the high degree of crossreactivity between the somatic antigens of $A$. simplex and somatic antigens of the ascaridoids $A$. suum, $T$. canis and $H$. aduncum, although several $A$. simplex components in the $11-18 \mathrm{kDa}$ range were only recognized by sera from mice infected with A. simplex. Tanaka et al. (1983) developed a radioimmunoassay for $A$. suum protein and observed that $T$. canis had a high concentration of a substance partially cross-reactive with A. suum protein. Also, small amounts of subtance cross-reacting with $A$. suum protein was also exhibited by Anisakis larvae. High concentrations of $A$. suum protein were observed in sera from patients with ascariasis $(64.5 \pm 18.8 \mathrm{ng} / \mathrm{ml})$, anisakiasis 
$(75.2 \pm 28.0 \mathrm{ng} / \mathrm{ml})$ and toxocariasis $(78.4 \pm 31.3 \mathrm{ng} / \mathrm{ml})$. Nunes et al. (1997) detected at least one band with molecular weight around $55-66 \mathrm{kDa}$ that seems to be responsible for the cross-reactivity between T. canis and A. suum once it disappears when previous absorption of serum samples with A. suum antigens was performed. Kennedy et al. (1989) observed, using radioimmunoprecipitation and SDS-PAGE, that there was a significant antigenic similarity between the antigens of $A$. suum and T. canis. Among the cross-reactive components, these authors found a 14 $\mathrm{kDa}$ internal protein which has a homologue in the two parasites, observing that was the subject of an IgG antibody response in Ascaris infection, but there was not measurable response to it in toxocariasis. McWilliams et al. (1987) observed that $A$. suum cross-reacted allergically with $T$. canis and that the cross-reacting allergens were predominatly of high molecular weight.

A. simplex PAK antigen was purified from the anti-A. suum rabbit IgG column. In the A. simplex PAS antigen the proteins of $A$. simplex PAK antigen were maintained but increased in intensity the bands of 40 and $14 \mathrm{kDa}$. In the A. simplex PAS antigen, the proteins were of $120,66-$ $45,40,31-21$ and $14 \mathrm{kDa}$ with elevated concentrations of these specific proteins that those observed in the nonpurified samples except in the case of the $14 \mathrm{kDa}$ protein. The eluted fractions which contained the cross-reacting antigens with $A$. suum showed bands in the ranges of molecular weight situated at 40 and $14 \mathrm{kDa}$, observing in the latter higher concentrations than in the specific antigen. In our experimental conditions, the minimal responses were observed by ELISA using sera from rabbits inoculated per os with T. canis embryonated eggs against all the antigenic preparations used. Conversely, the highest responses were obtained when the sera from rabbits immunized with larval $A$. simplex or adult $A$. suum $\mathrm{CE}$ were tested against their corresponding homologous and heterologous CE from A. simplex or A. suum. Further, we studied the different responses to the different antigenic preparations of A. simplex used, observing their capability of discriminating among the different antisera raised in rabbits. The discriminatory capability with the anti-T. canis antisera was good using the larval $A$. simplex $\mathrm{CE}$ antigen. When A. simplex PAK antigen was used, its capability for discriminate between A. simplex and A. suum was improved, increasing in the case of T. canis. The best results were obtained using $A$. simplex PAS antigen. When we compared the different serum dilution and antigenic concentration, we selected the working serum dilution of $1 / 400$ and $1 \mu \mathrm{g} / \mathrm{ml}$ of antigenic concentration. These conditions insure the maximal differences among the different sera using small quantities of the samples. Works are in progress to study the specificity and sensitivity of A. simplex antigens prepared by affinity chromatography using sera from human patients diagnosed of anisakidosis, ascariosis and visceral larva migrans by ELISA and western-blot techniques.

\section{REFERENCES}

Águila C del, Cuéllar C, Fenoy S, Guillén JL 1987. Comparative study of assay detecting circulating immuno-complexes and specific antibodies in patients infected with Toxocara canis. J Helminthol 61: 196-202.

Bradford M 1976. A rapid a sensitive method for the quantitation of microgram quantities of protein utilizing the principle of protein-dye-binding. Ann Biochem 72: 248.

Cuéllar C, Fenoy S, del Águila C, Guillén JL 1990. Evaluation of chemotherapy in experimental toxocarosis by determination of specific immune complexes. J Helminthol 64: 279289.

Christie JF, Dunbar B, Davidson I, Kennedy MW 1990. Nterminal amino acid sequence identity between a major allergen of Ascaris lumbricoides and Ascaris suum, and MHCrestricted IgE responses to it. Immunology 69: 596-602.

Christie JF, Dunbar B, Kennedy MW 1993. The ABA-1 allergen of the nematode Ascaris suum: epitope stability, mass spectrometry, and $\mathrm{N}$-terminal sequence comparison with its homologue in Toxocara canis. Clin Exp Immunol 92: 125-132.

Daniels JJHM 1962. De eosinofile flegmone van het maagdarmkanaal veroorzaakt door de haringworm. Ned Tijdschr Geneeskd 106: 131-132.

Fenoy S, Cuéllar C, Guillén JL 1987. Estudio comparativo de la influencia de la luz en el embrionamiento experimental de los huevos de Toxocara canis y Toxascaris leonina. Rev Ibér Parasitol Vol Ext: 173-177.

Fenoy S, Cuéllar C, Guillén JL 1988. Estudio comparativo de la influencia de la luz en el embrionamiento experimental de huevos de Toxocara canis, Toxascaris leonina y Ascaris suum. Rev Ibér Parasitol 48: 395-401.

García L, González ML, Esteban MI, Mirabent E, Perteguer MJ Cuéllar C 1996. Enzyme-linked immunosorbent assay, immunoblot analysis and RAST fluoroimmunoassay analysis of serum responses against crude larval antigens of Anisakis simplex in a Spanish random population. $J$ Helminthol 70: 281-289.

Guillén JL, Cuéllar C, del Águila C 1986. Fotodependencia del desarrollo embrionario de Toxocara canis (Werner, 1782) Stiles, 1905. Rev Ibér Parasitol 46: 67-74.

Hames BD 1986. An introduction to polyacrilamide gel electrophoresis. In BD Hames, D Rickwood (eds), Gel Electrophoresis in Proteins, IRL Press, Oxford.

Iglesias R, Leiro J, Ubeira FM, Santamarina MT, Navarrete I, Sanmartín ML 1996. Antigenic cross-reactivity in mice between third-stage larvae of Anisakis simplex and other nematodes. Parasitol Res 82: 378-381.

Ishikura H, Kikuchi K, Nagasawa K, Ooiwa T, Takamiya H, Sato N, Sugane K 1993. Anisakidae and anisakidosis. In T Sun, Progress in Clinical Parasitology, Vol. III, SpringerVerlag, New York.

Kato Y, Komatsu S 1996. ASABF, a novel cysteine-rich antibacterial peptide isolated from the nematode Ascaris suum. Purification, primary structure, and molecular cloning of cDNA. J Biol Chem 271: 30493-30498.

Kennedy MW, Qureshi F, Fraser EM, Haswell-Elkins MR, Elkins OB, Smith HV 1989. Antigenic relationships between the surface-exposed, secreted and somatic materials of the nematode parasites Ascaris lumbricoides, Ascaris suum and Toxocara canis. Clin Exp Immunol 75: 493-500.

Kennedy MW, Tierney J, Ye P, McMoanagle FA, McIntosh A, McLaughlin D, Smith JW 1988. The secreted and somatic antigens of the third stage larva of Anisakis simplex, and antigenic relationship with Ascaris suum, Ascaris lumbricoides, and Toxocara canis. Mol Biochem Parasitol 31: 35-46.

Laemmli UK 1970. Cleavage of structural proteins during the assembly of the head of bacteriophage T4. Nature 227: 680 . McWilliams AS, Stewart GA, Turner KJ 1987. An immuno- 
logical investigation of the allergens from Ascaris suumperienteric fluid. Cross-reactivity, molecular weight distribution and correlation with phosphorilcholine-containing components. Int Arch Allergy Appl Immunol 82: 125132.

Nunes CM, Tundisi RN, García JF, Heinemann MB, Ogassawara S, Richtzenhain LJ 1997. Cross-reactions between Toxocara canis and Ascaris suum in the diagnosis of visceral larva migrans by western blotting technique. Rev Inst Med Trop São Paulo 39: 253-256.

Perteguer MJ, Cuéllar C 1998. Isotype-specific immune responses in murine experimental anisakiasis. $J$ Vet Med B 45: 603-610.

Ruitemberg EJ 1970. Anisakiasis: Pathogenesis, Serodiagnosis and Prevention, Thesis, University of Utrecht, Netherlands.

Sakanari JA, McKerrow JH 1989. Anisakiasis. Clin Microbiol Rev 2: 278-284.

Smith JW, Wootten R 1978. Anisakis and Anisakiasis. In WHR
Lumsden, K Muller, JK Baker (eds), Advances in Parasitology, Vol. 16, Academis Press, London.

Suzuki T 1968. Studies on the immunological diagnosis of anisakiasis. Japan J Parasitol 17: 213-220.

Tanaka K, Kawamura H, Tohgi N, Tsuji M, Miyachi Y, Miyoshi A 1983. The measurement of Ascaris suum protein by radioimmunoassay in sera from patients with helminthiasis and with gastrointestinal diseases. Parasitology 86: 291300.

Welch JS, Symons MH, Dobson C 1983. Immunodiagnosis of parasitic zoonoses: purification of Toxocara canis antigens by affinity chromatography. Int J Parasitol 13: 171-178.

Yahiro S, Cain G, Butler JE 1998. Identification, characterization and expression of Toxocara canis nematode polyprotein allergen TBA-1. Parasite Immunol 20: 351-357.

Zarnowska H, Jartrzebska M 1994. Excretory-secretory larval antigens of Toxocara canis: physico-chemical characteristics and specificity assayed by Western blot technique. Acta Parasitol 39: 41-45. 